\title{
Aldosterone Excretion in Normal Children and in Children with Adrenal Hyperplasia *
}

\author{
Maria I. New, $\dagger$ Barbara Miller, and Ralph E. Peterson $\neq$ \\ (From the Departments of Pediatrics and Medicine, Cornell University Medical College, \\ New York, N. Y.)
}

The salt-wasting aspect of congenital adrenal hyperplasia may be explained either by the absence of aldosterone, by the presence of a salt-excreting factor, or both.

Since patients with this disorder manifest other signs of 21-hydroxylase deficiency such as increased urinary pregnanetriol ${ }^{1}$ and decreased cortisol production, a deficient synthesis of aldosterone, a 21-hydroxylated steroid, is predictable.

Conclusions have differed as to whether the saltexcreting factor or the aldosterone deficiency is the more important cause of the salt wasting, or more specifically, sodium wasting. This investigation has utilized the double isotope dilution derivative technique to study the excretion of the various urinary metabolites of aldosterone in a large number of normal children and children with congenital adrenal hyperplasia. This technique has not heretofore been used to establish standards of aldosterone excretion in a large number of normal children ranging in age from prematurity

* Submitted for publication June 18, 1965; accepted December 2, 1965.

These studies were supported by grants AM04855, HD00072, training grant AM5350, and Research Career Award 5-K6-AM-14,241, National Institutes of Health.

This investigation was also aided by grant FR47, Division of General Medical Sciences, National Institutes of Health.

Abstract submitted to the Thirty-fourth Meeting of the Pediatric Research Society, Seattle, Wash., June 1964. Published in J. Pediat. 1964, 65, 1123.

$\uparrow$ Address requests for reprints to Dr. Maria I. New, The New York Hospital-Cornell Medical Center, 525 East 68th Street, New York, N. Y. 10021.

$\ddagger$ Career scientist.

1 The following names and their trivial names and $a b-$ breviations are used: $3 \alpha, 17 \alpha, 20 \alpha$-trihydroxy-5 $\beta$-pregnane (pregnanetriol) ; tetrahydroaldosterone $=$ THA; $\mathrm{pH} 1$ hydrolyzable aldosterone $=3$ oxoconjugate $(\mathrm{pH} 1) ; 17 \alpha$, 21 dihydroxy-pregn 1,4 diene, $3,11,20$ trione (prednisone); $11 \beta 17 \alpha, 21$-trihydroxy-pregn 1,4 diene, 3,20-dione (prednisolone ) ; hydrocortisone $=$ cortisol $=$ compound $\mathrm{F}$; 11 deoxycorticosterone $=\mathrm{DOC}$. to adolescence. The results indicate that normal children metabolize aldosterone similarly to adults. When corrected for surface area, aldosterone excretion in normal children and patients with simple virilizing congenital adrenal hyperplasia is equivalent to that in adults. In children with saltwasting congenital adrenal hyperplasia, however, these levels are very low. These results support the hypothesis that aldosterone deficiency is an important factor in salt-wasting adrenal hyperplasia.

\section{Methods}

\section{Double isotope dilution derivative assay of aldosterone and tetrahydroaldosterone}

Urinary free (unconjugated) aldosterone and aldosterone released by $\mathrm{pH} 1$ hydrolysis (3-oxoconjugate) were measured by a modification of the double isotope dilution derivative technique of Kliman and Peterson $(1,2)$. A double isotope dilution derivative method has been devised for urinary tetrahydroaldosterone glucuronide. This method and the modification of the aldosterone methods published previously $(1,2)$ are presented below.

Reagents. Dichlormethane, anhydrous benzene, cyclohexane, mesitylene, isoöctane, and carbon tetrachloride were purified by passage through a bed of silica gel averaging 100 mesh in a $7-\times 130-\mathrm{cm}$ column and collected in $3-\mathrm{L}$ portions. Ten to $20 \mathrm{~L}$ can be purified in 2 to 3 hours. The solvents remain reasonably free of impurities for many months at room temperature.

Dioxane, reagent grade, was purified by distillation through a fractionation column over $\mathrm{NaOH}$ pellets.

Pyridine was refluxed over barium oxide for 4 to 6 hours and distilled through a fractionation column. The middle fraction boiling at $115^{\circ}$ was collected.

Acetic anhydride was refluxed over calcium carbide for 4 to 6 hours and distilled through a fractionation column. The middle fraction boiling at $139^{\circ}$ was collected.

Glacial acetic acid was refluxed over an excess of chromium trioxide for 4 to 6 hours. The chromate was removed by decantation and the acetic acid distilled over fresh chromium trioxide through a fractionation column. The middle fraction boiling at $118^{\circ}$ was collected. Fresh chromium trioxide was added and the distillation repeated. (Caution: do not add chromium trioxide to hot acetic acid.) An occasional batch of reagent grade 
glacial acetic acid may be satisfactory if distilled through an efficient fractionation column. A brand of acetic acid distilled over chromium trioxide can also be obtained.2

Chromium trioxide in $0.5 \%$ glacial acetic acid was prepared in the following manner: $50 \mathrm{mg}$ of reagent grade chromium trioxide was dissolved in $10 \mathrm{ml}$ redistilled glacial acetic acid containing $0.1 \mathrm{ml}$ water. This reagent keeps for 1 to 2 weeks only. It should be discarded if it shows appreciable darkening.

Benzylhydrazide, $0.5 \mathrm{mg}$ per $\mathrm{ml}$ methanol, was employed. The benzylhydrazide ${ }^{3}$ is first purified by recrystallization from methanol.

Acetic anhydride- $1-{ }^{14} \mathrm{C}$ and tritium acetic anhydride in $20 \%$ benzene (vol/vol) were obtained.4 These were stored in a fume hood in a small ground glass stoppered ampule within a closed container containing benzene over $\mathrm{CaCl}_{2}$. It may remain reasonably free of radioactive impurities for a few weeks; however, if it is of very high specific activity (greater than $100 \mathrm{mc}$ per mmole), it should be redistilled in vacuum bimonthly or weekly.

To provide a phosphor solution, we dissolved $4 \mathrm{~g}$ of PPO (2,5-diphenyloxazole) and $0.04 \mathrm{~g}$ POPOP (1,4-di2-phenyloxazole) in benzene 5 in $1 \mathrm{~L}$ of reagent grade toluene. A $4 \%$ solution of Liquifluor ${ }^{5}$ in toluene may also be used.

Beta glucuronidase (Ketodase) ${ }^{6}$ contained $5,000 \mathrm{U}$ per $\mathrm{ml}$.

To obtain $0.5 \mathrm{M}$ acetate buffer, $\mathrm{pH} 5$, we mixed 60 $\mathrm{ml}$ of $0.5 \mathrm{M}$ acetic acid $(29.4 \mathrm{ml}$ glacial acetic acid diluted to $1 \mathrm{~L}$ with water) with $140 \mathrm{ml}$ of $0.5 \mathrm{M}$ sodium acetate ( $41.0 \mathrm{~g}$ sodium acetate per $\mathrm{L}$ of water).

Aldosterone of high specific activity (aldosterone-1,2${ }^{8} \mathrm{H}, 90 \mu \mathrm{c}$ per $\mu \mathrm{g}$, and aldosterone- $4-{ }^{14} \mathrm{C}, 0.12 \mu \mathrm{c}$ per $\mu \mathrm{g}$ ) was obtained 4 and purified by chromatography on paper in the solvent system benzene: methanol: water $(4: 2: 1)$ for 10 to 12 hours. Prednisone migrates with aldosterone in this system and is a convenient marker. The aldosterone was eluated and made to volume with ethanol.

Preparation of labeled tetrahydroaldosterone. The labeled aldosterone was redissolved in $0.1 \mathrm{ml}$ of methanol followed by $2 \mathrm{ml}$ of $0.1 \mathrm{M}$ Tris buffer, ${ }^{7} \mathrm{pH}$ 7.4. The following were added to the buffered mixture: $0.2 \mathrm{ml}$ of $0.2 \mathrm{M} \mathrm{MgCl}_{2} ; 0.2 \mathrm{ml}$ triphosphopyridine nucleotide (NADP), $72 \mathrm{mg}$ per $\mathrm{ml}$ in Tris buffer, $\mathrm{pH} 7.4 ; 0.2 \mathrm{ml}$ of $0.2 \mathrm{M}$ isocitric acid, ${ }^{7}$ the trisodium salt in Tris buffer, adjusted to $\mathrm{pH} 7.4$ with $1 \mathrm{~N} \mathrm{HCl}$; and $0.2 \mathrm{ml}$ of isocitric acid dehydrogenase, $710 \mathrm{mg}$ per $\mathrm{ml}$. After mixing, $3 \mathrm{ml}$ of a solution of the soluble fraction of rat liver prepared as follows was added.

Approximately $100 \mathrm{~g}$ of rat liver was homogenized

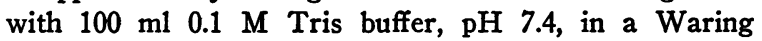
blendor at a moderate speed for 2 to 3 minutes. Young female rats weighing between 150 and $225 \mathrm{~g}$ were used, and the liver of each of these rats weighed approximately

\footnotetext{
2 Eastman Chemical Co., Rochester, N. Y.

3 Eastman Chemical Co., Rochester, N. Y.

4 New England Nuclear Corp., Boston, Mass.

s Pilot Chemical Co., Watertown, Mass.

6 Warner-Chilcott, Morris Plains, N. J.

7 Sigma Chemical Corp., St. Louis, Mo.
}

$10 \mathrm{~g}$. The animals were killed by decapitation, and the liver was promptly removed and cut into small pieces before homogenization. All steps in the preparation were carried out at $4^{\circ} \mathrm{C}$. The homogenate was centrifuged in the cold at $10,000 \times g$ for 10 minutes. The supernatant was then centrifuged in the Spinco preparative ultracentrifuge at $100,000 \times g$ for 1 hour.

After incubation of aldosterone with the soluble rat liver enzyme preparation, the labeled steroid was extracted with $40 \mathrm{ml}$ dichlormethane. The upper aqueous layer was discarded by aspiration and the solvent washed with 0.1 vol $0.1 \mathrm{~N} \mathrm{NaOH}$; after removal of the alkaline aqueous layer, the solvent was washed with $0.1 \mathrm{M}$ acetic acid. After the acetic acid was discarded, the solvent was evaporated to dryness in an air stream. The residue was chromatographed on paper in the solvent system benzene: methanol: water $(4: 2: 1)$ for 24 to 30 hours. Prednisolone may be used as a marker in this system, and in 24 hours it migrates $35 \mathrm{~cm}$ and tetrahydroaldosterone (3-alpha, 5-beta), $36 \mathrm{~cm}$. The labeled tetrahydroaldosterone was eluted and acetylated with acetic anhydride and pyridine and chromatographed on paper in the solvent system isoöctane: methanol: water (10: $10: 1)$ for 24 hours and subsequently in the cyclohexane: dioxane: methanol: water $(10: 2: 10: 2)$ system for 12 to 14 hours. The tetrahydroaldosterone triacetate was eluted with methanol and the alcohol evaporated to dryness. The residue was dissolved in $0.2 \mathrm{ml}$ methanol followed by addition of $4 \mathrm{ml}$ of a solution of acetyl cholinesterase ${ }^{8}$ (100 $\mathrm{U}$ per $1 \mathrm{ml}$ of $0.1 \mathrm{M}$ Tris buffer, $\mathrm{pH}$ 7.4). The acetate was hydrolyzed by incubation of this mixture at $37^{\circ}$ for 18 hours. The free steroid was extracted with dichlormethane and the solvent washed with $0.1 \mathrm{~N} \mathrm{NaOH}$ and $0.1 \mathrm{M}$ acetic acid. The solvent was evaporated to dryness and the steroid again chromatographed in the benzene: methanol: water system for 20 to 24 hours.

Determination of specific activity of labeled acetic anhydride. Labeled acetic anhydride $(0.02 \mathrm{ml}$, use syringe and micropipette) and anhydrous pyridine $(0.02 \mathrm{ml})$ were added to $400 \mu \mathrm{g}$ of dry cortisol. The tube was closed tightly with a glass stopper. After overnight incubation at $25^{\circ}, 1 \mathrm{ml} 25 \%$ ethanol in water was added to the reaction mixture. The cortisol acetate was extracted from the ethanol-water with 5 vol dichloromethane. The ethanol-water was removed by aspiration into a vacuum flask containing a strong alkali and connected to a water pump vacuum. The dichloromethane was washed twice with $1 \mathrm{ml}$ water and the water removed by aspiration. A small quantity of ethanol was added to the dichloromethane, and the solvents were evaporated to dryness with an air stream in a water bath at 35 to $40^{\circ}$ in a well-ventilated fume hood. The cortisol acetate was applied on one thin line covering the width of Whatman no. 1 paper $(18-\times 55-\mathrm{cm})$ and chromatographed in the solvent system cyclohexane: benzene: methanol: water $(10: 4: 10: 2)$ for 50 to 60 hours. The acetate was located with a $254-\mathrm{m} \mu$ ultraviolet light source and eluted from the paper with ethanol. The eluate applied along a

8 Nutritional Biochemicals, Cleveland, Ohio. 
thin line covering one-third the width of ethanol-washed paper was rechromatographed for 16 to 18 hours in the solvent system cyclohexane: dioxane : methanol: water $(100: 100: 50: 25)$. The acetate was eluted with 20 to $25 \mathrm{ml}$ redistilled ethanol purified sufficiently so that the alcohol gives no significant absorption at $242 \mathrm{~m} \mu$. The concentration of cortisol acetate was determined by one or more of the following methods: 1) Absorption in ethanol in a Beckman DU spectrophotometer at $242 \mathrm{~m} \mu$ (molar absorbancy index-16, 200); 2) phenylhydrazine reaction in sulfuric acid-ethanol (Porter-Silber reaction) with recrystallized cortisol acetate $\left(\mathrm{mp} 225^{\circ}\right)$ as reference standard; 3) fluorometric assay with sulfuric acid-ethanol with cortisol acetate as reference standard. For measurement in the ultraviolet spectrum, it is imperative that an appropriate paper blank be assayed. The specific activity was expressed as counts per minute per millimicromole and determined by counting a sample of the eluate in the liquid scintillation spectrometer.

Method of collection of urine. Urines were collected for 24 hours, and after addition of a few drops of glacial acetic acid they were frozen. The urine must be stored at a $\mathrm{pH}$ slightly below neutrality. For secretion rates, urine was collected for two 24-hour periods after administration of 2 to $3 \mu \mathrm{c}$ of aldosterone-1,2- ${ }^{8} \mathrm{H}$ intravenously in $5 \%$ ethanol solution in $5 \%$ glucose in water. In the first 24 hours, 53 to $69 \%$ of the isotope was excreted, and in the second 24 hours 1 to $4 \%$ was excreted (10). The secretion rate 9 was calculated according to the method of Peterson (3). Both 3-oxoconjugate and tetrahydroaldosterone metabolites were used to measure aldosterone turnover rate.

\section{Preparation of samples}

Urinary 3-oxoconjugate of aldosterone. A 15- to 30-ml sample of fresh urine (as much as $25 \%$ of 24 -hour urine volume was used if the level of aldosterone was predicted to be low) or urine preserved by freezing was transferred to a ground glass stoppered cylinder approximately ten times the sample volume. A known quantity of aldosterone-4- ${ }^{14} \mathrm{C}$ (about 4,000 dpm) was added to the sample and mixed. For each $10 \mathrm{ml}$ of urine, 0.1 to 0.15 $\mathrm{ml}$ of concentrated $\mathrm{HCl}$ was added. The $\mathrm{pH}$ was adjusted to 1.0 with a $\mathrm{pH}$ meter by adding additional acid. The acidified urine was left at room temperature for 24 hours, and under these conditions 80 to $85 \%$ of the 3-oxoconjugate was hydrolyzed (1).

Urinary free (unconjugated) aldosterone. Approximately 10 to $25 \%$ of the 24-hour urine volume was added to a ground glass stoppered cylinder of approximately 10 times the sample volume. Aldosterone-4- ${ }^{14} \mathrm{C}$ (about 4,000 $\mathrm{dpm}$ ) was added to the sample and mixed.

Urinary tetrahydroaldosterone glucosiduronate. A 20to $50-\mathrm{ml}$ portion of urine was transferred to a small beaker containing approximately 4,000 dpm of tetrahydroaldosterone-4- ${ }^{14} \mathrm{C}$. Five $\mathrm{ml}$ of acetate buffer, $\mathrm{pH}$ 5.0, was added to the urine and this adjusted to a $\mathrm{pH}$ of 4.8 to

\footnotetext{
- Secretion rate, turnover rate, and production rate of aldosterone are used synonymously.
}

5.0 with a $\mathrm{pH}$ meter by adding additional glacial acetic acid, drop by drop. After addition of 1,000 U of Ketodase per $\mathrm{ml}$ of urine, the buffered urine was incubated at $37^{\circ}$ for 24 hours.

Extraction. Six to eight vol of dichloromethane was added to the urine and the mixture vigorously shaken for 15 to 20 seconds. The upper aqueous layer was discarded by aspiration. The dichloromethane extracts were washed with one-tenth vol $0.1 \mathrm{~N} \mathrm{NaOH}$. The alkaline aqueous layer was discarded and the solvent washed with one-tenth vol of $0.1 \mathrm{M}$ acetic acid. After the acetic acid was discarded, a few milliliters of ethanol was added and the dichloromethane extract evaporated to dryness in a beaker placed in an air stream from a fan. The residue was dissolved in a small volume of ethanol and transferred to a 30 - to $40-\mathrm{ml}$ conical glass-stoppered tube and evaporated to dryness. The following liquid-liquid partition was necessary for the free aldosterone assay in adults and in all childrens' samples. The dichloromethane extracts of urinary free aldosterone must first be dissolved in a small volume of ethanol and water added to a concentration of $25 \%$ ethanol in water. This was extracted with 5 vol of cyclohexane and the cylohexane removed by aspiration. The aqueous solution was then extracted with 7 vol of dichloromethane and the aqueous layer removed by aspiration. The dichloromethane was washed with a small volume of water, and after its removal by aspiration the dichloromethane was evaporated to dryness.

Chromatography of free steroid. Approximately 0.03 $\mathrm{ml}$ of a saturated solution of isatin (2,3 diketoindoline) in ethanol was added to the urine extracts containing aldosterone; $40 \mu \mathrm{g}$ of prednisolone was added to the urine extracts containing tetrahydroaldosterone. The residues were applied with disposable 22-cm transfer pipettes 10 to a thin $2.5-\mathrm{cm}$ line on Whatman no. 1 paper and chromatographed in the solvent system benzene: methanol: water $(4: 2: 1)$. The samples containing aldosterone were chromatographed for 10 to 12 hours, and in this system aldosterone and isatin migrate 35 to $40 \mathrm{~cm}$. The tetrahydroaldosterone was chromatographed for 20 to 24 hours, and tetrahydroaldosterone and prednisolone migrate 30 to $35 \mathrm{~cm}$. Paper strips were cut and the aldosterone and tetrahydroaldosterone accurately located by running each strip through a Vanguard paper strip radio scanner. If marked streaking occurred in the chromatography of the free steroid, an additional chromatography was carried out before acetylation, utilizing Whatman no. 3 paper and the solvent system benzene: methanol: water $(4: 2: 1)$ for 6 hours. The samples for urinary free aldosterone were eluted and rechromatographed in the cyclohexane: dioxane: water $(10: 10: 2.5)$ system for 14 to 16 hours. In this system, aldosterone and isatin migrate 30 to $35 \mathrm{~cm}$ in 14 to 16 hours.

The bands of paper containing the labeled steroids were cut out and the steroids eluted with methanol in small test tubes. The methanol was dried under an air stream. The labeled steroids were transferred to ground glass stop-

10 Clay-Adams, New York, N. Y. 
pered acetylation tubes ( 6.5 conical tubes, $13-\mathrm{mm}$ diameter $\times 90$-mm length) ${ }^{11}$ with two washes of small volumes ( 1 to $2 \mathrm{ml}$ ) of dichloromethane, and the solvent was evaporated to dryness. Some batches of purified dichloromethane may contain a water soluble impurity that will destroy free aldosterone and tetrahydroaldosterone, and for this reason the dichloromethane must be freshly repurified by washing with liberal amounts of distilled water.

Acetylation. Before acetylation, the tubes were placed in a desiccator over $\mathrm{CaCl}_{2}$ and evacuated overnight or in a vacuum oven at room temperature at pressure of 1 to $10 \mathrm{~mm} \mathrm{Hg}$ for 30 to 60 minutes. After $0.02 \mathrm{ml}$ anhydrous pyridine followed by $0.02 \mathrm{ml}$ of tritium-labeled acetic anhydride ( $100 \mathrm{mc}$ per mmole) was added to each tube, they were stoppered very tightly. Tritium-labeled acetic anhydride of $500 \mathrm{mc}$ per mmole was used for the urinary free aldosterone samples. A hood was used during this preparation. The pyridine and acetic anhydride were measured from microvolumetric pipettes stored in a desiccator over $\mathrm{CaCl}_{2}$ until ready for use. A syringe was used to transfer the acetic anhydride to the micropipette. The tubes were rotated manually to dissolve the residue and incubated for 18 to 24 hours at $24^{\circ}$.

After incubation, $35 \mu \mathrm{g}$ of aldosterone diacetate, $1.0 \mathrm{ml}$ $25 \%$ ethanol in water, and $5 \mathrm{ml}$ carbon tetrachloride were added to the samples containing aldosterone. The tetrahydroaldosterone samples were treated in the same way except that aldosterone diacetate was omitted. The tubes were shaken vigorously for 10 to 15 seconds, and the aqueous layer discarded by aspiration into a vacuum bottle containing strong alkali. The carbon tetrachloride was washed twice with $1 \mathrm{ml}$ water and the aqueous layer discarded. The samples were dried under an air stream at 35 to $40^{\circ}$ in a water bath in a well-ventilated hood. A small amount of ethanol was added to each tube to hasten drying and removal of water.

\section{Chromatography of, acetates}

Aldosterone diacetate. The residues were chromatographed on paper for 14 to 16 hours at $27^{\circ}$ in the solvent system cyclohexane : benzene: methanol: water (10:4:10: 2 ). No more than 3 spots should be applied to a single paper $18 \times 55 \mathrm{~cm}$. The blue textile dye F-11 12 was used as a visible reference marker to provide a more precise control of the rate of migration of the aldosterone diacetate. F-11 migrates 40 to $45 \mathrm{~cm}$ in 14 to 16 hours, and aldosterone diacetate, as visualized by $254 \mathrm{~m} \mu$ ultraviolet light source, migrates 35 to $40 \mathrm{~cm}$ in 14 to 16 hours.

The band of paper containing the aldosterone diacetate was cut out and the steroid eluted with methanol. The eluate was dried and chromatographed (four samples may be applied to all subsequent chromatographies) in the solvent system cyclohexane: dioxane: methanol: water $(10: 7.5: 7.5: 2.5)$ for 16 to 18 hours. Aldosterone diacetate migrates 30 to $35 \mathrm{~cm}$ and the red dye marker rhodamine $\mathrm{B}, 40$ to $45 \mathrm{~cm}$. The aldosterone diacetate was again eluted and chromatographed for 20 to 24 hours in

\footnotetext{
11 Kontes Glass Co., Vineland, N. J.

12 Ciba Pharmaceutical Co., Summit, N. J.
}

the solvent system mesitylene: methanol: water $(3: 2: 1)$. This was used as a reverse phase system. After the spots were applied, the paper was dipped through the upper layer (nonpolar) of solvent to approximately $1.5 \mathrm{~cm}$ of the starting line containing the applied spots. It was not necessary to impregnate the area of the paper above the starting line. The impregnated paper was blotted and hung up to dry for 3 minutes, placed in the chromatography tank, and the lower layer (polar) added without previous equilibration. Aldosterone diacetate migrates 30 to $35 \mathrm{~cm}$ in 20 to 24 hours and rhodamine $B$, 35 to $40 \mathrm{~cm}$.

Satisfactory purification of the 3-oxoconjugate is achieved after this third chromatography of the diacetate of aldosterone. For the urinary free aldosterone, the following additional purification was required: After the third chromatography of the diacetate, $0.3 \mathrm{ml}$ of the benzylhydrazide in methanol was added to the dried eluate and the alcohol evaporated to dryness under an air stream at 30 to $35^{\circ}$. The residue was chromatographed for 50 to 60 hours in the solvent system isoöctane: $t$-butanol: methanol: water $(10: 6: 10: 3)$. The benzylhydrazone derivative of aldosterone diacetate migrates 5 to 7 $\mathrm{cm}$ and the benzylhydrazide reagent, 9 to $11 \mathrm{~cm}$.

Tetrahydroaldosterone triacetate. The acetylated residues were first chromatographed on paper in the solvent system isoöctane: methanol: water $(10: 10: 1)$ for 30 to 36 hours. A small amount of orange textile dye F-65 12 was added to each sample before chromatography. Tetrahydroaldosterone triacetate migrates with the orange dye at $35 \mathrm{~cm}$. In each set of assays, tritium or ${ }^{14}$ carbonlabeled tetrahydroaldosterone triacetate was run as a separate spot to compare its migration with that of the dye marker. After chromatography, the paper strip containing the standard was run through a Vanguard paper strip scanner, and the tetrahydroaldosterone triacetate radioactivity was related to the migration of the dye marker. The bands of paper containing the tetrahydroaldosterone triacetates were cut out and the steroid eluted with methanol. The eluate was dried and the residue chromatographed in the solvent system cyclohexane: dioxane: methanol: water $(10: 2: 10: 2)$ for 12 to 14 hours. In this system, tetrahydroaldosterone triacetate migrates $35 \mathrm{~cm}$ and F-65, $38 \mathrm{~cm}$. Again the labeled tetrahydroaldosterone triacetate was located by reference to the migration of the standard acetate and the dye marker. The eluates of the tetrahydroaldosterone triacetates were collected in "oxidation tubes" (20-ml ground glass stoppered round bottom tubes, $21 \mathrm{~mm}$ in diameter, $115 \mathrm{~mm}$ in length), 11 and $0.2 \mathrm{ml}$ of freshly prepared $0.5 \%$ chromium trioxide in glacial acetic acid was added to each of the dried eluates. The tubes were rotated manually to let the solution wet all the residue and left at room temperature for 15 to 20 minutes. One $\mathrm{ml}$ of distilled water was added and the steroid extracted with $10 \mathrm{ml}$ dichloromethane. The dichloromethane was washed with $1 \mathrm{ml}$ of distilled water and the water discarded by aspiration. After again removing the aqueous layer, we evaporated the solvent to dryness and chromatographed each sample in the solvent system cyclohexane: benzene: methanol : water (100: 
25:100:10) for 12 to 14 hours. The blue textile dye F-11 was added to each sample before chromatography. In this system the oxidation product of tetrahydroaldosterone triacetate migrates $31 \mathrm{~cm}$ and the yellowish fluorescent spot in the dye marker $30 \mathrm{~cm}$, whereas the blue dye spot is at $20 \mathrm{~cm}$.

About one-half of the samples were determined by a method slightly different from those described above. The methods differed as follows: The eluates of the aldosterone diacetate after the second chromatography as aldosterone diacetate [cyclohexane: dioxane: methanol: water $(10: 7.5: 5.2: 2.5)]$ were treated in the following manner.

The eluates of the aldosterone diacetate were oxidized in the same manner as described for tetrahydroaldosterone. Each sample was chromatographed for 16 to 18 hours in the solvent system cyclohexane:benzene: methanol: water $(4: 3: 4: 1)$. The oxidation product of aldosterone diacetate migrates 25 to $30 \mathrm{~cm}$ in 16 to 18 hours.

The oxidized steroid was again eluted and chromatographed for 18 to 24 hours in the solvent system cyclohexane: dioxane: methanol: water $(10: 10: 5: 2.5)$. The oxidized steroid migrates $30 \mathrm{~cm}$ in 18 hours.

The steroid acetates for radioactivity assays were eluted and prepared for counting as indicated above.

Most of the samples of oxidized tetrahydroaldosterone diacetate were taken out of phosphor and chromatographed in the solvent system cyclohexane: dioxane: methanol: water $(10: 2: 10: 1)$. The marker used to locate the oxidized tetrahydroaldosterone triacetate was androst-1,4-diene-3,17-dione, which migrated $36 \mathrm{~cm}$, whereas the steroid acetate migrated $35 \mathrm{~cm}$ in 36 hours. The specificity of the assay was checked by noting the tritium to ${ }^{14}$ carbon ratio in the last three sequential steps.

Recovery of steroid acetates from phosphor. The toluene was evaporated to dryness in the counting vial. The residue was disolved in $0.5 \mathrm{ml}$ ethanol, and $2.5 \mathrm{ml}$ of water was added to the ethanol. The solution was allowed to stand for 1 hour and then filtered through Whatman no. 1 paper. The precipitate was washed with $4 \mathrm{ml}$ of $20 \%$ ethanol. The filtrate was extracted with 7 vol of dichloromethane and the upper aqueous layer discarded. The dichloromethane was evaporated to dryness, and the residue was ready for the next procedure. This method gives a yield of approximately $50 \%$ of the labeled steroid acetates.

Radioactivity assay. The steroid acetates for radioactivity assay were eluted with ethanol directly into counting vials and dried under an infrared lamp and in an air stream from a fan. The tritium and ${ }^{20}$ carbon were measured simultaneously at a constant photomultiplier voltage (approximately $1,170 \mathrm{v}$ ) in a Packard Tri-Carb scintillation spectrometer (model 314E). Net counts per minute ${ }^{14} \mathrm{C}=\mathrm{N}_{\mathrm{B}}-\mathrm{aN} \mathrm{N}_{\Delta}$, and net counts per minute ${ }^{8} \mathrm{H}=$ $N_{A}-\left(N_{B} / b\right)$, where $N_{B}=$ the observed counts per minute above background in the lower channel (discriminator, 10 to $50 \mathrm{v}$; gain, 80 ), and $N_{A}=$ observed counts per minute above background in the upper channel (discriminator, 10 to $60 \mathrm{v}$; gain, 100). a = ratio $\mathrm{N}_{\mathrm{B}} / \mathrm{N}_{\mathrm{A}}$ for tritium, and $b=$ ratio $N_{B} / N_{\Delta}$ for ${ }^{11}$ carbon. Since a was small $(0.005)$, b (2.0) could be substituted for the term $b-a$ in the equation (4).

The precision of measurement was $+2 \%$ for ${ }^{14} \mathrm{C}$ on the upper channel, $0.5 \%$ for ${ }^{14} \mathrm{C}$ on the lower channel, and $3 \%$ for tritium. For optimal precision, the ${ }^{3} \mathrm{H} /{ }^{14} \mathrm{C}$ ratio should be 0.1 to 100 . The efficiency for tritium was $33 \%$ and for ${ }^{14}$ carbon, 65\% (model 314E) (5).

The steroid concentration was calculated as follows: $\mathrm{H}_{1} / \mathrm{H}_{0} \times \mathrm{C} / \mathrm{S}_{\mathrm{c}} \times \mathrm{mol} \mathrm{wt} / 1,000 \times(24$ hour urine volume/ volume urine extracted) $=$ (micrograms aldosterone or tetrahydroaldosterone per 24-hour urine volume), where $\mathrm{H}_{1}=$ counts per minute ${ }^{14} \mathrm{C}$ added to the sample; $\mathrm{H}_{0}=$ counts per minute ${ }^{14} \mathrm{C}$ in the counting vial; $\mathrm{C}=$ counts per minute ${ }^{8} \mathrm{H}$ in the counting vial; $\mathrm{S}_{\mathbf{c}}=$ specific activity steroid diacetate (counts per minute ${ }^{8} \mathrm{H}$ per millimicromole); and mol wt $=$ molecular weight of free steroid. If the weight of added aldosterone $\left(H_{1}\right)$ is very small, it need not be included in the calculations (5).

Specificity. The specificity of the method was evaluated by the constant specific activity of the aldosterone in the two final successive steps. For aldosterone, this was assessed by the ${ }^{8} \mathrm{H} /{ }^{14} \mathrm{C}$ ratio after the chromatography of aldosterone diacetate in the reverse phase system mesitylene: methanol: water $(3: 2: 1)$ (ratio $\mathrm{A}$, Table I), and after chromatography of the derivative, aldosterone diacetate benzylhydrazone in the solvent system isoöctane: $t$-butanol : methanol: water $(10: 6: 10$ : 3) (ratio $B$, Table I).

For tetrahydroaldosterone the constancy of specific activity was evaluated by the ${ }^{8} \mathrm{H} /{ }^{14} \mathrm{C}$,ratio in the two final successive purification steps, i.e., after the second chromatography of the oxidation product of tetrahydroaldosterone in the solvent system cyclohexane : dioxane : methanol: water $(10: 2: 10: 1$ ) (ratio $A$, Table II), and after the residue from this chromatography was treated with benzylhydrazide and chromatographed in the system cyclohexane: benzene: methanol: water $(10: 2.5: 10: 1)$ (ratio $\mathrm{B}$, Table II). The benzylhydrazide does not react with the oxidized product of tetrahydroaldosterone, but it may react with impurities.

The specificity of the aldosterone method was also indicated by the identical results on four urine samples when two different derivatives were formed. The results were the same whether aldosterone was assayed by forming the oxidation product of aldosterone diacetate, as indicated by Kliman and Peterson (1), or by forming the aldosterone diacetate benzylhydrazone derivative (Table III).

Although no children who had been adrenalectomized

TABLE I

${ }^{3} \mathrm{H}$ to ${ }^{14} \mathrm{C}$ ratio $\mathrm{in}$ two final successive purification steps after acetylation of aldosterone with tritiated acetic anhydride

\begin{tabular}{lcccccccc}
\hline \multicolumn{1}{c}{ Sample } & 1 & 2 & 3 & 4 & 5 & 6 & 7 & 8 \\
\hline $\begin{array}{l}\text { Ratio A } \\
\text { Ratio B } \\
\mu \text { a aldosterone per } \\
\text { 24-hour urine volume }\end{array}$ & 13 & 245 & 12 & 24 & 179 & 65 & 29 & 135 \\
& 12 & 230 & 12 & 25 & 177 & 55 & 28 & 130 \\
\hline
\end{tabular}


TABLE II

${ }^{3} H$ to ${ }^{14} \mathrm{C}$ ratio in two final successive purification steps after acetylation of tetrahydroaldosterone with ${ }^{14} \mathrm{C}$-labeled acetic anhydride

\begin{tabular}{|c|c|c|c|c|c|c|c|c|}
\hline Sample & 1 & 2 & 3 & 4 & 5 & 6 & 7 & 8 \\
\hline Ratio A & 3.7 & 2.5 & 3.3 & 3.4 & 4.0 & 2.3 & 4.3 & 391 \\
\hline $\begin{array}{l}\text { Ratio B } \\
\boldsymbol{\mu g} \text { tetrahydro- } \\
\quad \text { aldosterone per 24- }\end{array}$ & 4.4 & 3.4 & 4.1 & 4.6 & 5.8 & 2.7 & 5.5 & 392 \\
\hline hour urine volume & 13 & 18 & 17 & 25 & 10 & 22 & 15 & 0.17 \\
\hline
\end{tabular}

were studied, three children with obvious Addison's disease excreted 0 to $0.01 \mu \mathrm{g}$ aldosterone and tetrahydroaldosterone daily. The reagent blanks of this method have been evaluated by Peterson (2).

The over-all recovery of added tritiated or ${ }^{14} \mathrm{C}$-labeled aldosterone ranged from 7 , to $12 \%$ for the free aldosterone assay, 7 to $16 \%$ for the 3-oxoconjugate, and 7 to $10 \%$ for tetrahydroaldosterone.

Precision of the assay for aldosterone is indicated in the duplicate determinations on nine samples (Table IV).

The sensitivity of the method is limited by the specific activity of the radioactive acetic anhydride, and the accuracy depends on the purity of the added labeled aldosterone and the isolated aldosterone. When using ${ }^{8} \mathrm{H}-\mathrm{la}$ beled acetic anhydride, $100 \mathrm{mc}$ per mmole, assuming a $10 \%$ recovery, and demanding $100 \%$ more counts per minute than background, this method is sensitive to $2.5 \mathrm{~m} \mu \mathrm{g}$ of aldosterone.

Normal values of urinary aldosterone excretion in adults were: 3 -oxoconjugate, 5 to $20 \mu \mathrm{g}$ per day; tetrahydroaldosterone, 15 to $80 \mu \mathrm{g}$ per day; and free aldosterone, 0.05 to $0.2 \mu \mathrm{g}$ per day. Plasma cortisol was determined by the method of Peterson (7). Urinary 17-hydroxycorticoids were assayed by the method of Peterson and associates (8). Urinary 17-ketosteroids were assayed by the method of Peterson (9). Serum and urinary sodium and potassium were determined by flame photometry. Urinary pregnanetriol was assayed by a new isotope dilution method to be published. The normal values of urinary pregnanetriol when this method was used were : prepubescent children, 0 to $0.2 \mathrm{mg}$ per 24 hours; and adolescents and adults, 0.05 to $0.2 \mathrm{mg}$ per 24 hours.

TABLE III

Aldosterone values on four different urine samples assayed by forming two different derivatives

\begin{tabular}{|c|c|}
\hline $\begin{array}{l}\text { Oxidation } \\
\text { Aldosterone } \\
\text { diacetate }\end{array}$ & $\begin{array}{c}\text { Benzyl- } \\
\text { hydrazone } \\
\text { Aldosterone } \\
\text { diacetate }\end{array}$ \\
\hline \multicolumn{2}{|c|}{$\mu g / d a y$} \\
\hline $\begin{array}{c}0.63 \\
19 \\
7 \\
86\end{array}$ & $\begin{array}{c}0.62 \\
18 \\
7 \\
88\end{array}$ \\
\hline
\end{tabular}

TABLE IV

Duplicate determination of urinary aldosterone*

\begin{tabular}{ccccccccccc}
\hline Sample & 1 & 2 & 3 & 4 & 5 & 6 & 7 & 8 & 9 \\
\hline \multicolumn{10}{c}{$\mu g / 24$} & hours \\
1st assay & 13 & 0.13 & 39 & 15 & 14 & 6 & 2.0 & 6.2 & 19 \\
2nd assay & 12 & 0.11 & 36 & 15 & 15 & 7 & 1.8 & 5.0 & 19 \\
\hline * Coefficient of variation $=9.8 \%(6)$. \\
Results
\end{tabular}

Aldosterone excretion in normal children and children with adrenal hyperplasia. When corrected for surface area, the excretion of the 3-oxoconjugate of aldosterone and the tetrahydroaldosterone glucuronide was equivalent to that of adults in 42 normal children of all ages and in 14 children with simple virilizing adrenal hyperplasia. When corrected for surface area, the urinary excretion of free aldosterone in young infants was greater than that of adults, but in older children it was similar to adults (Figures 1-3, Tables V-VII). Patients with simple virilizing adrenal hyperplasia who were untreated did not show consistently higher levels of aldosterone excretion than those who were treated. Three of the nine patients with untreated simple virilizing adrenal hyperplasia excreted

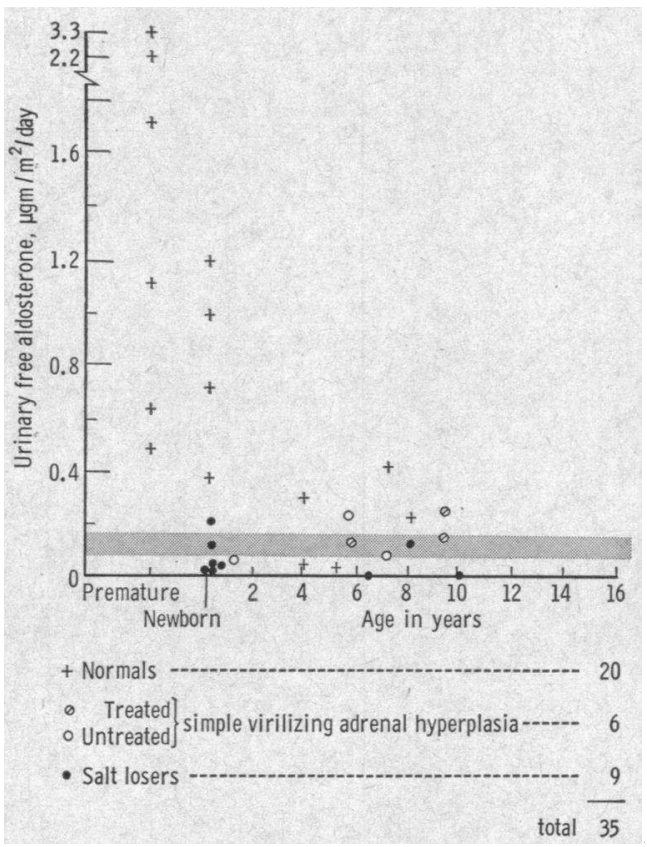

Fig. 1. ExCRETION RATES OF FREe ALDOSTERone corRECTED FOR SURFACE AREA. Shaded area represents adult normal values corrected for surface area. 


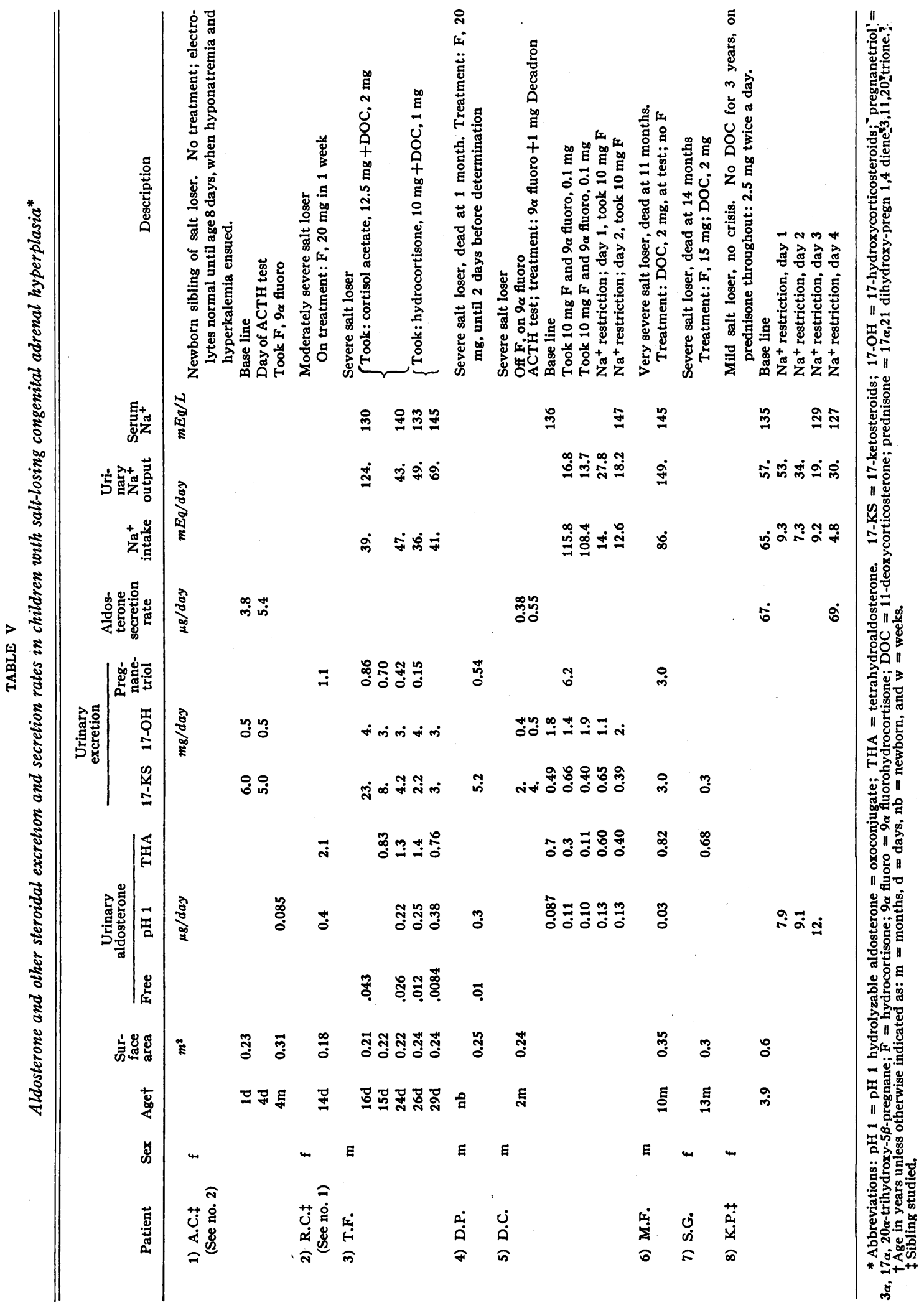




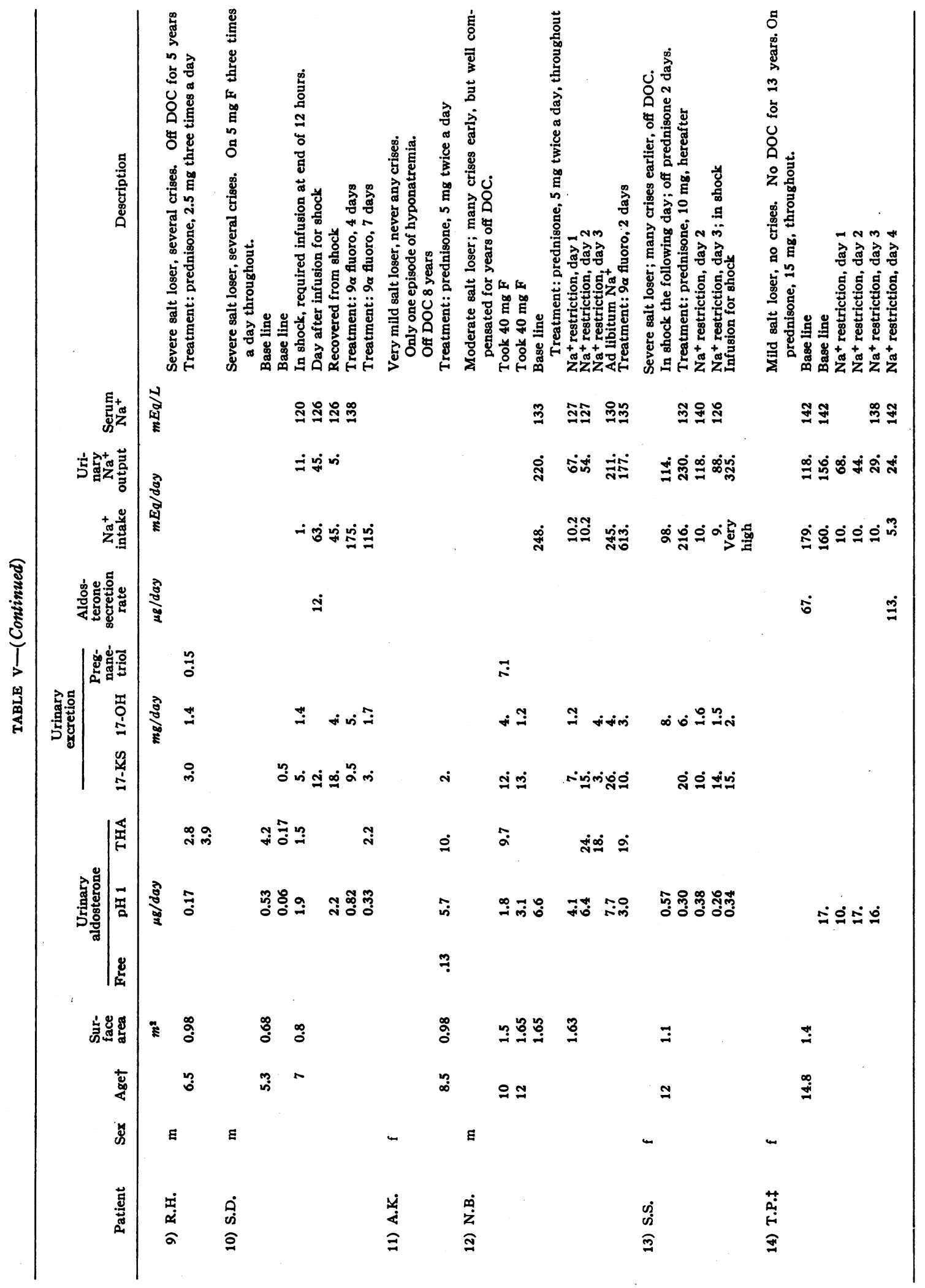




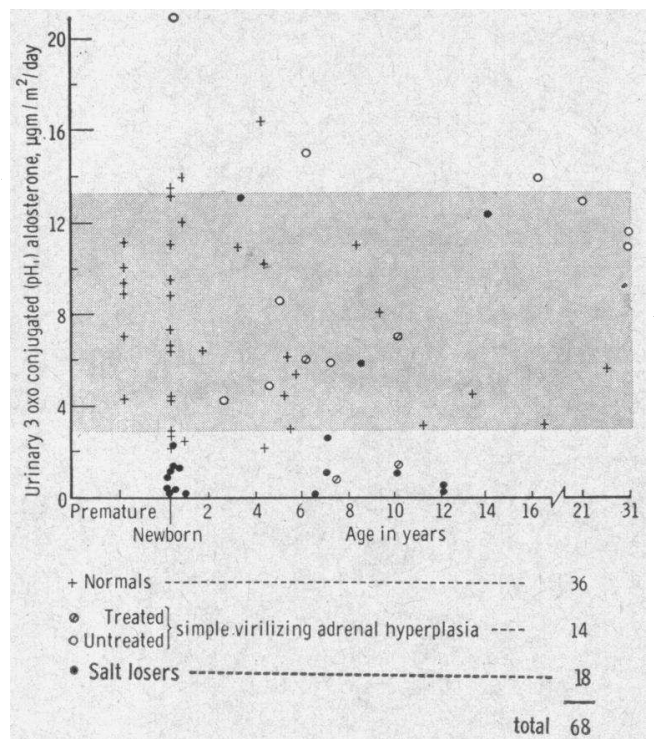

Fig. 2. ExCretion Rates of the 3-oxoconjugate of ALDOSTERONE CORRECTED FOR SURFACE AREA. Shaded area represents adult normal values corrected for surface area.

higher than normal levels of aldosterone when corrected for surface area, whereas none of the five treated patients exceeded the normal range. Excretion of aldosterone metabolites (3-oxoconjugate and tetrahydroaldosterone glucuronoside) was lower than normal in 11 children with the salt-losing form of adrenal hyperplasia. The exceptions to this were three patients (K.P., A.K., and T.P., Table V) who had only one episode of mild hyponatremia and hyperkalemia, and whose subsequent clinical picture did not indicate repetition of this difficulty despite the absence of mineralocorticoid treatment.

Two of the patients (D. I. and N.J., Table VI), who were clinically classified as suffering from simple virilizing congenital adrenal hyperplasia excreted very low levels of aldosterone (both 3-oxoconjugated and tetrahydroaldosterone glucuronide). One of these patients (D.I.) is the 71year-old sibling of S.I. (no. 5), whose aldosterone excretion is normal. Clinically, D.I. is a salt craver, whereas S.I. is not (see Table VI).

\section{Sodium restriction experiments}

A) Patients with salt-losing congenital adrenal hyperplasia. Seven patients with salt-losing adrenal hyperplasia were subjected to sodium restriction. A typical study of the sodium intake, urinary sodium, serum electrolytes, weight, and aldosterone excretion or secretion rates is illustrated by Figure 4 .

The four salt losers with the most frequent episodes of crises (T.F., D.C., S.D., and S.S., Table V) had low base-line aldosterone levels, and their aldosterone excretion did not increase significantly with salt restriction. The three salt losers with less severe disease clinically (K.P., N.B., and T.P., Table V) started with normal levels of urinary aldosterone but showed no increase with sodium restriction. One of these patients (T.P.) did not demonstrate an increased aldosterone excretion on the third day of sodium restriction but did show an increase in the aldosterone turnover rate on the fourth day.

B) Patients with simple virilizing adrenal hyperplasia. Three patients with simple virilizing adrenal hyperplasia, (T.B., P.G., and P.S., Table VI) showed a more than threefold increase in their normal base-line urinary aldosterone (Figure 5). Two of these patients (T.B. and P.S.) had not been treated with glucocorticoid. These three patients, in contrast to the salt losers, showed a marked decrease in urinary sodium output with sodium restriction.

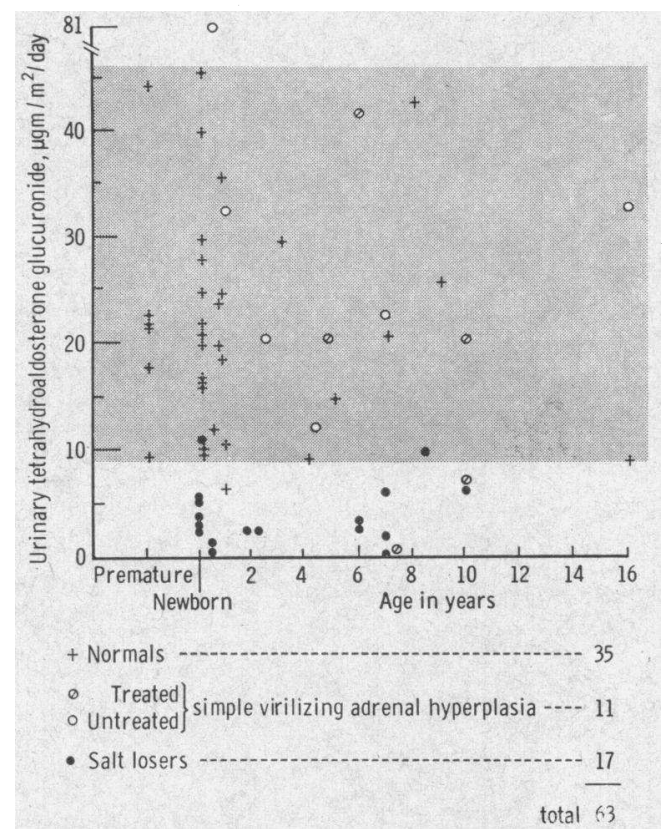

Fig. 3. EXCRETION RATES OF TETRAHYDROALDOSTERONE GLUCURONIDE CORRECTED FOR SURFACE AREA. Shaded area represents adult normal values corrected for surface area. 


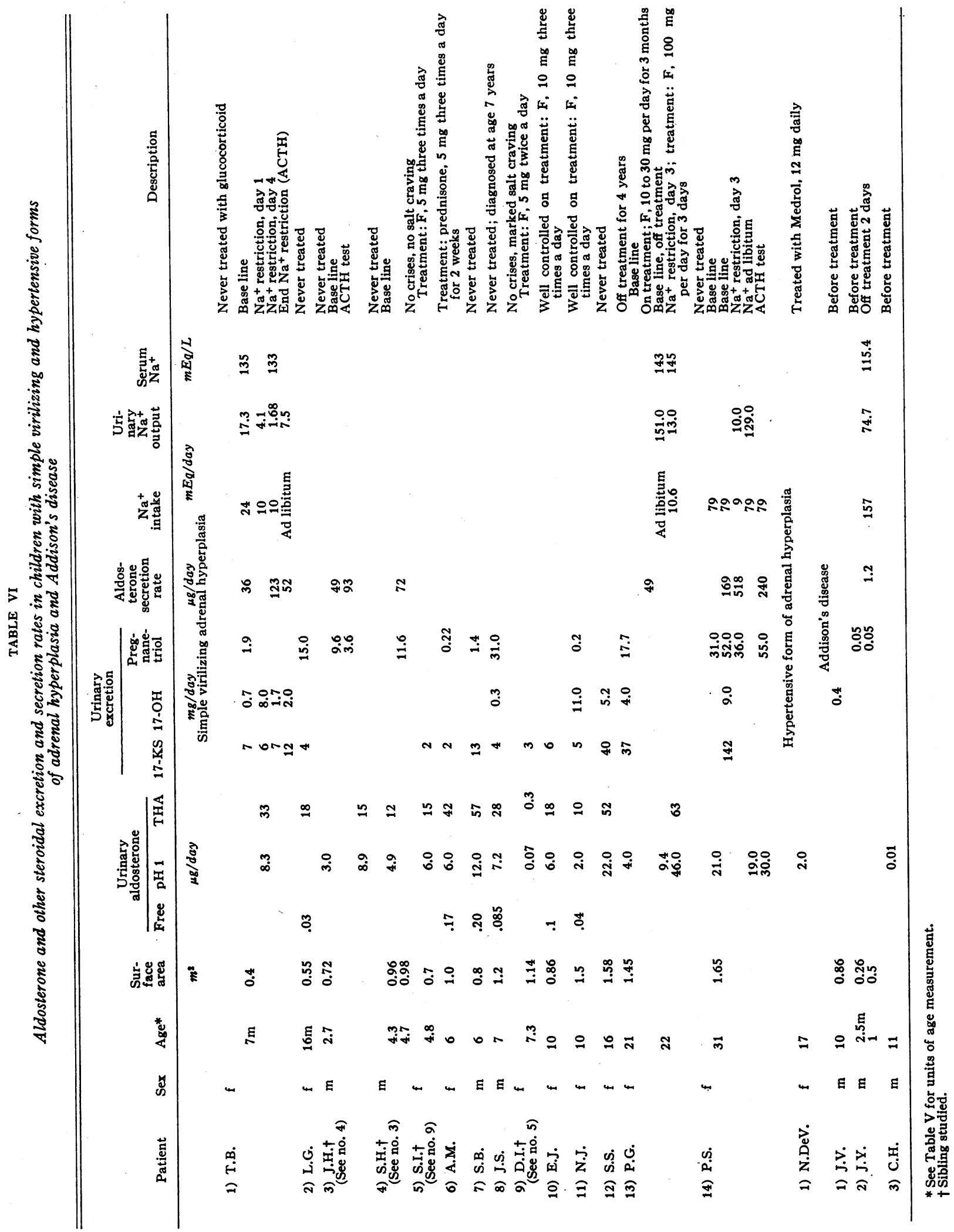




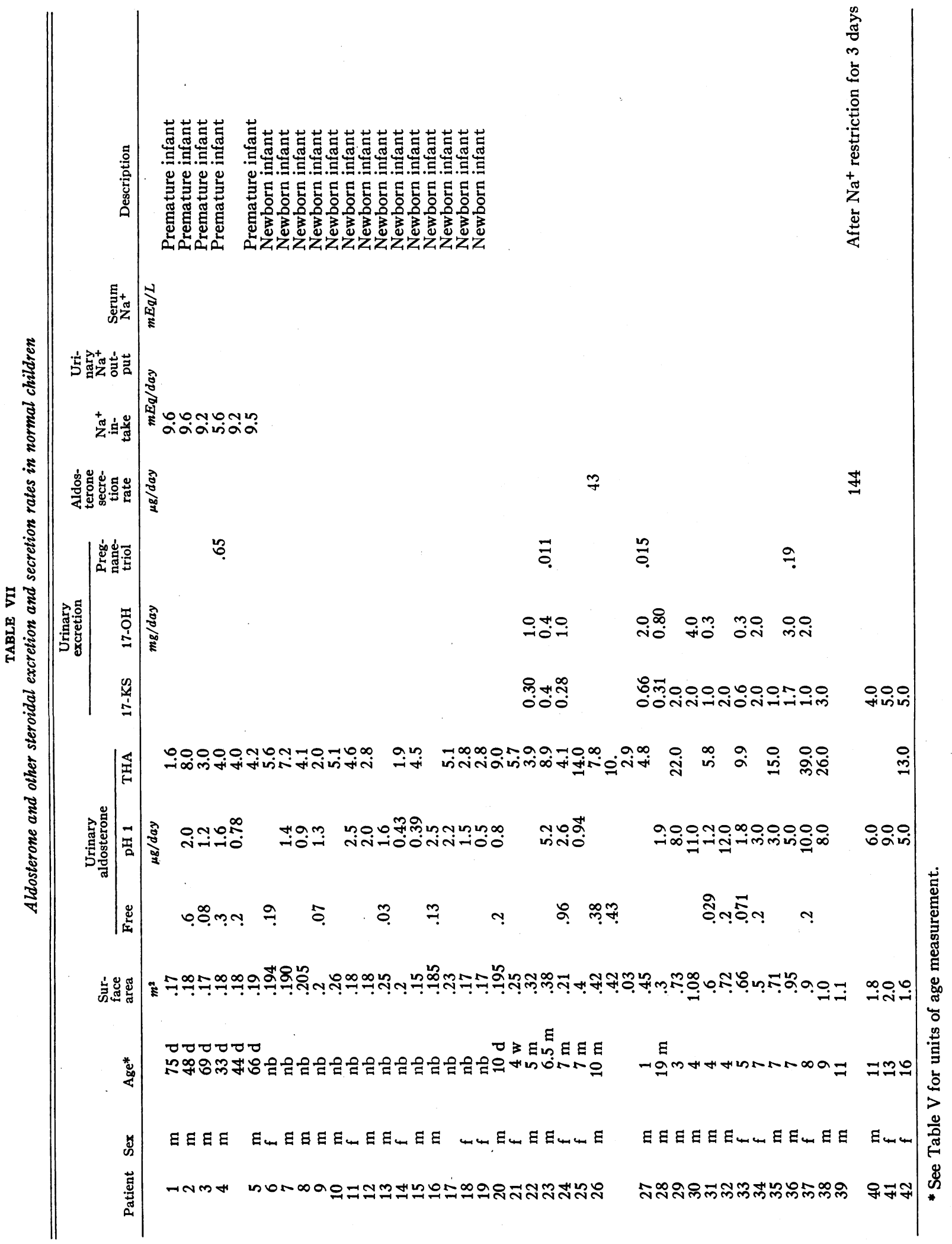


D.C., 2 mos $M$, salt losing adrenal hyperplasia
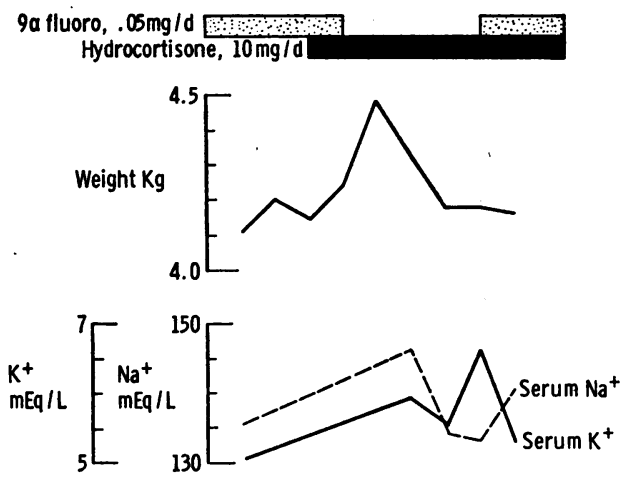

Aldo secretion rate $(\mu \mathrm{g} / \mathrm{d}) \quad 0.38 \quad 0.55$

Aldo excretion pHI (ug/d) $.087 \quad .11 .10 .13 .13$

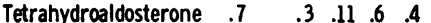

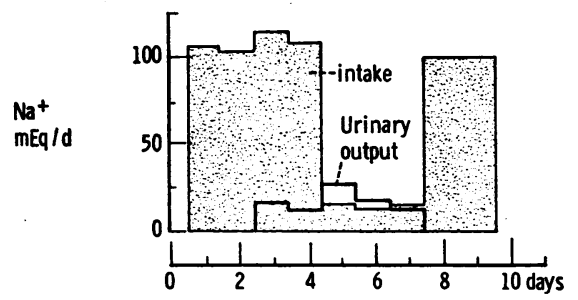

Fig. 4. A tYPICAL STUDY OF ALDOSTERONE EXCRETION OR SECRETION RATES DURING SODIUM RESTRICTION IN SALTLOSING CONGENITAL ADRENAL H YPERPLASIA. $9 \alpha$ fluoro $=9 \alpha$ fluoro hydrocortisone; $d=$ day.

C) Normal subject. A patient with no endocrine disorder (no. 39, Table VII) produced 144 $\mu \mathrm{g}$ of aldosterone after 4 days of restriction of dietary sodium to $10 \mathrm{mEq}$ daily.
P.G. 2lyrs F, simple virilizing adrẹnal hyperplasia
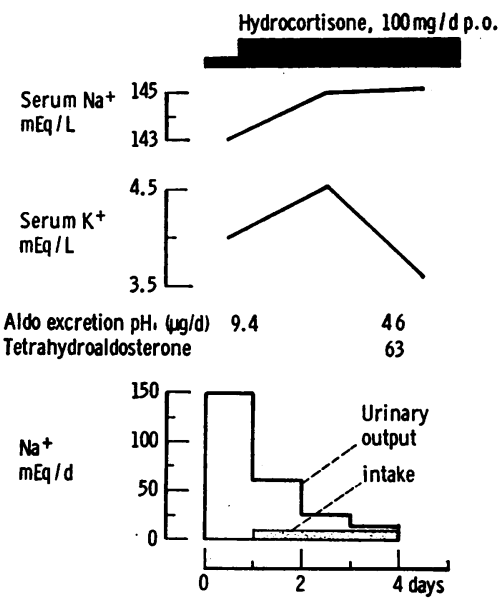

Fig. 5. A TYPICAL STUDY OF ALDOSTERONE OR SECRETION RATES DURING SODIUM RESTRICTION IN SIMPLE VIRILIZING CONGENITAL ADRENAL HYPERPLASIA. P.O. = orally.

Newborn untreated salt loser. A newborn virilized female sibling of a patient with salt-losing congenital adrenal hyperplasia (A.C., Table V) was studied in the first and second days of life before she manifested any electrolyte disorder. At this time the aldosterone turnover rate was 3.8 $\mu \mathrm{g}$ per day. At 4 months of age when the patient manifested the usual salt-wasting symptoms the urinary aldosterone excretion was very low (0.085 $\mu \mathrm{g}$ per day of 3-oxoconjugate).

Patient with hypertensive adrenal hyperplasia. A 17-year-old female pseudohermaphrodite with

TABLE VIII

Per cent of administered radioactive aldosterone appearing in urinary metabolites

\begin{tabular}{|c|c|c|c|c|}
\hline Subject Age & Condition & $\begin{array}{l}\text { Per cent } \\
\text { as free } \\
\text { aldosterone }\end{array}$ & $\begin{array}{l}\text { Per cent } \\
\text { as 3-oxo- } \\
\text { conjugate }\end{array}$ & $\begin{array}{l}\text { Per cent } \\
\text { as THA }\end{array}$ \\
\hline $\begin{array}{l}\text { Normal adults } \\
\text { Male W } \\
10 \text { months }\end{array}$ & $\begin{array}{l}\text { Absence of septum } \\
\text { pallucidum }\end{array}$ & $\begin{array}{c}0.1-0.33 \\
0.9\end{array}$ & $\begin{array}{l}5-12 \\
16.0\end{array}$ & $\begin{array}{c}20-40 \\
15.0\end{array}$ \\
\hline $\begin{array}{l}\text { Female L } \\
6 \text { months }\end{array}$ & $\begin{array}{l}\text { Absence corpus } \\
\text { callosum }\end{array}$ & 1.6 & & 12.0 \\
\hline $\begin{array}{r}\text { Female } M \\
6 \text { years }\end{array}$ & $\begin{array}{l}\text { Hypothalamic tumor, } \\
\text { sexual precocity }\end{array}$ & $\begin{array}{l}0.3 \\
0.2\end{array}$ & $\begin{array}{r}6.6 \\
13.0\end{array}$ & $\begin{array}{l}39.0 \\
33.0\end{array}$ \\
\hline $\begin{array}{l}\text { Male } W \\
12 \text { years }\end{array}$ & Exudative enteropathy & 0.15 & 8.0 & 45.0 \\
\hline $\begin{array}{l}\text { Male } Z \\
8 \text { years }\end{array}$ & Brain tumor & 1.2 & 8.0 & 25.0 \\
\hline $\begin{array}{l}\text { Male } P \\
3 \text { years }\end{array}$ & Sexual precocity & 0.3 & 25.0 & 32.0 \\
\hline $\begin{array}{l}\text { Male } T \\
5 \text { years }\end{array}$ & Obesity & 0.3 & & 22.0 \\
\hline $\begin{array}{l}\text { Female } G \\
21 \text { years }\end{array}$ & $\begin{array}{l}\text { Simple virilizing } \\
\text { adrenal hyperplasia }\end{array}$ & 0.4 & 9.4 & 26.5 \\
\hline
\end{tabular}


the hypertensive form of congenital adrenal hyperplasia (11-hydroxylase deficiency) excreted very low levels of 3-oxoconjugated aldosterone in the urine ( $2 \mu \mathrm{g}$ per day) (see Table VI).

Urinary excretion of metabolites of aldosterone. The metabolism of aldosterone in seven children with various disorders was studied by administering tritiated aldosterone (ring-labeled in the 1,2 position) and measuring the per cent of the administered aldosterone excreted as the free, the 3-oxoconjugate, and the tetrahydroaldosterone glucuronide. Ring-labeled aldosterone-4-14 $\mathrm{C}$ and ring-labeled tetrahydroaldosterone $-4-{ }^{14} \mathrm{C}$ were added to the urine to detect procedural losses. Results indicate that the ratio of metabolites of aldosterone in the urine of children of various ages and with various diseases was similar to that of adults (10) (Table VIII). The ratio of urinary metabolites of aldosterone remained constant in three patients on two separate studies. This would indicate that changes in urinary metabolite excretion of aldosterone in the same subjects reflect alterations in aldosterone production (11-13).

Addison's disease. Three patients with Addison's disease excreted no metabolites of aldosterone. The youngest patient (J.Y., Table VI) did not increase his turnover rate of aldosterone even when his serum $\mathrm{Na}$ was $115 \mathrm{mEq}$ per $\mathrm{L}$.

\section{Discussion}

The results indicate that aldosterone production is impaired in salt-losing adrenal hyperplasia, even under the stress of sodium restriction and hyponatremia, whereas it is not impaired in the simple virilizing type of adrenal hyperplasia. The level of aldosterone excretion in a large group of normal children is comparable to that of the adult when values are corrected for surface area. The ratio of metabolites of aldosterone in the urine of children is similar to that in the adult.

The normal aldosterone production in one infant with salt-losing adrenal hyperplasia before salt-wasting manifestations and the subsequent fall in aldosterone production when salt-wasting symptoms required treatment indicate an early capacity to produce aldosterone that is lost. The decrease in aldosterone production cannot be attributed to atrophy of the adrenal due to steroid treatment, since infants with simple virilizing adrenal hyperplasia on similar steroidal treatment retain the ca- pacity to produce normal amounts of aldosterone and to increase aldosterone with salt restriction.

The maintenance dosage of steroids used in treatment would not be sufficient to cause significant sodium retention. It would require a dose of 1 to $2 \mathrm{mg}$ of 11-deoxycorticosterone (DOC) or 25 to $50 \mathrm{mg}$ of hydrocortisone or $100 \mathrm{mg}$ of prednisone or prednisolone to cause the same mineralocorticoid activity of $50 \mu \mathrm{g}$ of aldosterone. Under conditions of sodium restriction the requirements would be 3 to 4 times higher. Thus, the maintenance doses of glucocorticoid used in these subjects should not decrease aldosterone production significantly $(14,15)$.

The low level of aldosterone excretion in the patient with the hypertensive form of congenital adrenal hyperplasia confirms the results of Kowarski and co-workers (16) and is in disagreement with the report by Holub and Barlow (17).

The data presented support the hypothesis that the salt-losing aspect of adrenal hyperplasia is caused by hypoaldosteronism. The inability to produce adequate amounts of aldosterone is probably due to a severe defect in 21-hydroxylation. This increased severity of the enzymic defect in salt-losing congenital adrenal hyperplasia when compared to the simple virilizing adrenal hyperplasia has been suggested by the lower levels of tetrahydrocortisone observed in salt losers (18, 19).

The various arguments that have been advanced for the importance of the salt-excreting factor (20) in causing salt wasting may be enumerated as follows.

1) The early data indicate normal to supernormal aldosterone levels in salt losers. Von Prader, Spahr, and Neher (21) in 1955 reported two cases of simple virilizing adrenal hyperplasia in adults and four cases of salt-losing adrenal hyperplasia in children, all of whom showed normal or supernormal aldosterone excretion with salt restriction. Normal daily urinary excretion values for children in this study were 0.3 to $3.5 \mu \mathrm{g}$ of the 3-oxoconjugate of aldosterone.

Luetscher (22) in 1956 gave values of 1 to 1.5 $\mu \mathrm{g}$ per day for normal children and stated (23) that children with salt-losing adrenal hyperplasia excrete normal amounts of aldosterone.

Jailer, Ulich, and Lieberman (24) in 1959 found the aldosterone secretion rate by the isotope dilu- 
tion assay to be normal in two salt losers and elevated in two out of three simple virilizers. They also reported no defect in cortisol secretion in the salt losers in whom ACTH produced sodium loss and adrenal crisis.

Rosemberg and co-workers (25) described a child with salt-losing adrenal hyperplasia studied at 18 months of age and again at $4 \frac{1}{2}$ years who excreted normal to high levels of aldosterone (23.8 $\mu$ g per day).

The investigators thus far cited concluded that there was no aldosterone deficiency in the saltlosing form of adrenal hyperplasia and that a saltexcreting factor was probably present.

On the other hand, Lieberman and Luetscher (26) in 1960 demonstrated little or no aldosterone in the urine of six infants with salt-losing adrenal hyperplasia but normal adult amounts in normal children.

Blizzard, Liddle, Migeon, and Wilkins (27), in a comprehensive study of normal children and children with salt-losing and simple virilizing adrenal hyperplasia, found that when salt was restricted normal children and simple virilizers showed an increase in aldosterone excretion, but salt losers did not.

Bryan, Kliman, and Bartter (28) measured aldosterone secretion and excretion in five salt losers who raised their aldosterone production only slightly when salt was restricted. The turnover rate of aldosterone ranged from 2 to $9 \mu \mathrm{g}$ daily at base line and increased to 6 to $28 \mu \mathrm{g}$ with salt restriction. Two normal children increased their aldosterone turnover rates from 112 and 26 to 432 and $205 \mu \mathrm{g}$ per day, respectively, whereas salt losers increased the excretion of the 3-oxoconjugate of aldosterone to a maximum of only $2.9 \mu \mathrm{g}$ per day with sodium deprivation.

Kowarski and co-workers (16) presented studies on two adult simple virilizers who increased their turnover rates of aldosterone from 306 and 350 to 434 and $600 \mu \mathrm{g}$ per day. Five salt losers whose base-line secretion rates ranged from 4 to 64 did not show an increase with salt restriction. A 12-year-old boy with the hypertensive form of adrenal hyperplasia also did not increase his baseline aldosterone secretion rate with sodium restriction, which is in disagreement with the report of normal aldosterone production in a similar patient by Holub and Barlow (17). The secretion rate of aldosterone in normal children was reported as 44 to $92 \mu \mathrm{g}$ per day by Kowarski (16).

Mattox and Lewbart (29) while using a modification of the Neher and Wettstein method (30) found the 3-oxoconjugate excretion in 25 children to be 0.7 to $18 \mu \mathrm{g}$ per $\mathrm{m}^{2}$ per day. Six patients with simple virilizing adrenal hyperplasia and six out of seven salt losers fell within the normal range of aldosterone excretion; however, the salt losers did not increase aldosterone excretion with salt restriction.

We (31) reported that salt losers have lower levels of aldosterone metabolites than simple virilizers and normal children of all ages.

Most recently several investigators (32-35) have reported low aldosterone secretion rates that did not increase with sodium restriction in salt losers, but normal aldosterone secretion rates in non-salt losers.

The conclusion reached by most of the research investigations $(16,26-29,31-35)$ is that an aldosterone deficiency does exist in congenital hyperplasia of the salt-losing variety, but not in the simple virilizing form.

The variation in results among different investigators may stem from an inadequacy of methods used in the earlier works. The bioassay method $(23,26,27)$ and the paper visualization method $(21-25,29,36)$ lack the sensitivity necessary to determine aldosterone at very low levels, and specificity of the methods usually was not adequately evaluated (37). Greatest reliance can be placed on those studies that properly utilized the highly sensitive and specific double dilution isotope derivative assay (1). Studies using this technique $(16,27$, $28,31,32$ ) have revealed an aldosterone deficiency.

2) The sodium loss caused by ACTH in adrenal hyperplasia and in newborns may be explained by a stimulation of the adrenal glands to produce a salt-losing hormone $(38-40)$. Although these investigations showed that there was some increase in sodium excretion on the day after intramuscular administration of ACTH, this need not be explained by the salt-excreting factor. Where volume of urine was reported, it was always increased with increased sodium loss. The sodium diuresis after ACTH could alternatively be explained by an increased glomerular filtration rate resulting from the ACTH-induced rise in plasma cortisol (4147). George, Saucier, and Bartter (48) suggest 
the possibility that the preparations of ACTH used may have been contaminated with vasopressin, which might have induced a renal sodium loss.

Finally, the response of patients with intact adrenal glands to ACTH is by no means constant and therefore serves as a poor reference for the response of salt losers. Apparently, normal subjects may show sodium diuresis or retention after ACTH (49-53).

It would appear, therefore, that sodium diuresis after ACTH in salt losers is not a strong argument for the importance of the salt-excreting factor in causing salt wasting.

3) Resistance to DOC has been described in patients with adrenogenital syndrome and has been used to support the thesis that the excessive DOC is required to counteract a salt-excreting factor $(S E F)$. The apparent resistance to $\mathrm{DOC}$ is based on a comparison of DOC dosages required by adults rather than by young infants. The DOC requirement of young infants, which would be a more appropriate reference, has not been clearly established. Therefore, the large DOC dosages required daily by young adrenogenital salt losers cannot be used as an argument for factors other than hypoaldosteronism as a cause of salt wasting until further data regarding DOC requirements of young infants are obtained. The patient with Addison's disease (J.Y.) was noted to have as high DOC requirement as any of the adrenogenital salt losers.

In summary, the data supporting the presence of SEF seem inconclusive at present. Attempts to isolate a salt-excreting hormone active in man have failed (54). On the other hand, specific methods have yielded a large body of data indicating an inability of the adrenogenital salt loser to increase aldosterone with salt restriction.

Hypoaldosteronism seems to be a reasonable explanation for the salt wasting observed in these patients.

\section{Summary}

A new double isotope dilution derivative method for assaying urinary tetrahydroaldosterone glucuronide and a modification of a previously published double isotope dilution derivative technique for urinary aldosterone are presented These are highly specific and sensitive determinations.

The double isotope dilution derivative technique was used to measure the excretion of the three major metabolites of aldosterone-free aldosterone, 3-oxoconjugate of aldosterone, and tetrahydroaldosterone glucuronide-in a large number of children of all ages, both normal and with saltlosing and simple virilizing adrenal hyperplasia. Secretion rates of aldosterone were also measured by the same technique.

When corrected for surface area, aldosterone levels of normal children and patients with simple virilizing adrenal hyperplasia are equivalent to those of adults, but are very low in children with salt-wasting adrenal hyperplasia.

Under the stress of salt restriction, salt losers cannot increase aldosterone production, but simple virilizers show a threefold increase.

The ratio of aldosterone metabolites in the urine of children is similar to that in the urine of adults.

These results support the hypothesis that aldosterone deficiency is an important factor in saltwasting adrenal hyperplasia.

\section{Acknowledgments}

We wish to thank Drs. A. M. Bongiovanni and A. Root for supplying the urine from the 17 -year-old patient with 11-hydroxylase deficiency. We are appreciative of the technical help of Miss A. Andersen and Mrs. Vita Amendolagine.

\section{References}

1. Kliman, B., and R. E. Peterson. Double isotope derivative assay of aldosterone in biological extracts. J. biol. Chem. 1960, 235, 1639.

2. Peterson, R. E. Determination of peripheral plasma aldosterone in Aldosterone, E. E. Baulieu and P. Robel, Eds. Oxford, Blackwell, 1964.

3. Peterson, R. E. The miscible pool and turnover rate of adrenocortical steroids in man. Recent Progr. Hormone Res. 1959, 15, 231.

4. Okita, G. T., J. J. Kabara, F. Richardson, and G. V. LeRoy. Assaying compounds containing $\mathrm{H}^{8}$ and $C^{14}$. Nucleonics 1957, 15, 111.

5. Peterson, R. E., and E. A. Eilers. The use of labeled acetic anhydride in steroid assays. Proceedings of the International Congress of Endocrinology. Amsterdam, Excerpta Medica International Congress Series, 1964, no. 83, p. 267.

6. Snedecor, G. W. Statistical Methods. Ames, Iowa State College Press, 1956.

7. Peterson, R. E. The determination of plasma cortisol in Standard Methods of Clinical Chemistry. New York, Academic Press, 1960, vol. 3.

8. Peterson, R. E., J. B. Wyngaarden, S. L. Guerra, B. B. Brodie, and J. J. Bunim. The physiological 
disposition and metabolic fate of hydrocortisone in man. J. clin. Invest. 1955, 34, 1779.

9. Peterson, R. E. Determination of urinary neutral 17-ketosteroids in Standard Methods in Clinical Chemistry. New York, Academic Press, 1963, vol. 4.

10. Peterson, R. E. Studies of radioactive aldosterone in man in Isotopes in Experimental Pharmacology, L. J. Roth, Ed. Chicago, University of Chicago Press, 1965, p. 177.

11. Peterson, R. E. Unpublished data.

12. Flood, C., D. S. Layne, S. Ramcharan, E. Rossipal, J. F. Tait, and S. A. S. Tait. An investigation of the urinary metabolites and secretion rates of aldosterone and cortisol in man and a description of methods for their measurement. Acta endocr. (Kbh.) 1961, 36, 237.

13. Jones, K. M., R. Lloyd-Jones, A. Riondel, J. F. Tait, S. A. S. Tait, R. D. Bulbrook, and F. C. Greenwood. Aldosterone secretion and metabolism in normal men and women and in pregnancy. Acta endocr. (Kbh.) 1959, 30, 321.

14. Prunty, F. T. G. Chemistry and Treatment of Adrenocortical Diseases. Springfield, Ill., Charles C Thomas, 1964.

15. Kleeman, C. R., and M. H. Maxwell. Abnormalities associated with diseases of the endocrine glands in Clinical Disorders of Fluid and Electrolyte Metabolism, M. H. Maxwell and C. R. Kleeman, Eds. New York, McGraw-Hill, 1962, p. 352.

16. Kowarski, A., J. W. Finkelstein, J. S. Spaulding, G. Holman, and C. J. Migeon. Aldosterone secretion rates (ASR) in congenital adrenal hyperplasia. The Society for Pediatric Research Program and Abstracts, 34th Annual Meeting 1964, 2.

17. Holub, D. A., and J. J. Barlow. Synthesis of aldosterone in hypertensive congenital adrenal hyperplasia with complete deficiency of $11 \beta$ hydroxylation (abstract). The Endocrine Society, Program of the 43rd Meeting 1961, 16.

18. Eberlein, W. R. The salt-losing form of congenital adrenal hyperplasia. Pediatrics 1958, 21, 667.

19. Mattox, V. R., A. B. Hayles, R. M. Salassa, and F. R. Dion. Urinary steroid patterns and loss of salt in congenital adrenal hyperplasia. J. clin. Endocr. 1964, 24, 517.

20. Klein, R. Evidence for and against the existence of a salt-losing hormone. J. Pediat. 1960, 57, 452.

21. Von Prader, A., A. Spahr, and R. Neher. Erhöte Aldosteronaus-scheidung beim kongenitalen adrenogenitalen Syndrom. Ein Beitrag zur Pathogenese des Syndroms. Schweiz. med. Wschr. $1955,85,1085$.

22. Luetscher, J. A. Studies of aldosterone in relation to water and electrolyte balance in man. Recent Progr. Hormone Res. 1956, 12, 175.

23. Luetscher, J. A. Adrenal function in infants and children. Reports of the Ross (M\&R) 13th Pediatric Research Conferences, November 1954.
24. Jailer, J. W., S. Ulich, and S. Lieberman. Aldosterone and hydrocortisone secretion rates in patients with the salt-losing form of congenital adrenal hyperplasia. Trans. Ass. Amer. Phycns 1959, 72, 149 .

25. Rosemberg, E., F. X. Dufault, Jr., E. Bloch, E. Budnitz, P. Butler, and J. Brem. The effects of progressive reduction of sodium intake on adrenal steroid excretion and electrolyte balance in a case of congenital adrenal hyperplasia of the salt-losing type. J. clin. Endocr. 1960, 20, 214.

26. Lieberman, A. H., and J. A. Luetscher. Some effects of abnormalities of pituitary, adrenal or thyroid function on excretion of aldosterone and the response to corticotropin or sodium deprivation. J. clin. Endocr. 1960, 20, 1004.

27. Blizzard, R. M., G. W. Liddle, C. J. Migeon, and L. Wilkins. Aldosterone excretion in virilizing adrenal hyperplasia. J. clin. Invest. 1959, 38, 1442.

28. Bryan, G. T., B. Kliman, and F. C. Bartter. Impaired aldosterone production in "salt-losing" congenital adrenal hyperplasia (abstract). Clin. Res. 1962, 10, 223.

29. Mattox, V. R., and M. L. Lewbart. The determination of aldosterone in urine. J. clin. Endocr. 1959, 19, 1151.

30. Neher, R., and A. Wettstein. Physicochemical detection and measurement of aldosterone in body fluids and tissues. Acta endocr. (Kbh.) 1955, 18, 386.

31. New, M. I., B. Miller, and R. E. Peterson. Excretion of aldosterone metabolites in normal children and in children with adrenal hyperplasia. The Society for Pediatric Research Program and Abstracts, 34th Annual Meeting 1964, 51.

32. Degenhart, H. J., H. K. A. Visser, R. Wilmink, and W. Croughs. Aldosterone and cortisol secretion rates in infants and children with congenital adrenal hyperplasia suggesting different 21-hydroxylation defects in salt-losers and non salt-losers. Acta endocr. (Kbh.) 1965, 48, 587.

33. Henkin, R. I., G. T. Bryan, and F. C. Bartter. Aldosterone secretion in congenital adrenal hyperplasia (abstract). J. clin. Invest. 1965, 44, 1058.

34. Bryan, G. T., B. Kliman, and F. C. Bartter. Impaired aldosterone production in "salt-losing" congenital adrenal hyperplasia. J. clin. Invest. 1965, 44, 957.

35. Kowarski, A., J. W. Finkelstein, J. S. Spaulding, G. H. Holman, and C. J. Migeon. Aldosterone secretion rate in congenital adrenal hyperplasia. A discussion of the theories on the pathogenesis of the salt-losing form of the syndrome. $\mathrm{J}$. clin. Invest. 1965, 44, 1505.

36. Nowaczynski, W., E. Koiw, and J. Genest. Chemical method for the determination of urinary aldosterone. Canad. J. Biochem. 1955, 35, 425.

37. Tait, J. F. Methods in Hormone Research. New York, Academic Press, 1962, vol. 1, p. 265. 
38. Wilkins, L., R. Klein, and R. A. Lewis. The response to ACTH in various types of adrenal hyperplasia in Proceedings of the First Clinical ACTH Conference, J. R. Mote, Ed. Philadelphia, Blakiston, 1950, p. 184.

39. Lewis, R. A., and L. Wilkins. The effect of adrenocorticotrophic hormone in congenital adrenal hyperplasia with virilism in Cushing's syndrome treated with methyl testosterone. J. clin. Invest. 1949, 28, 394.

40. Klein, R. Adrenocortical control of sodium and potassium excretion in the newborn period. J. clin. Invest. 1951, 30, 318.

41. Liddle, G. W. Effects of anti-inflammatory steroids on electrolyte metabolism. Ann. N. Y. Acad. Sci. $1959,82,854$.

42. Soffer, L. J. The adrenal gland and its effect on electrolyte and fluid distribution in Edema: Mechanism and Management, J. H. Moyer and M. Fuchs, Eds. Philadelphia, Saunders, 1960, p. 107.

43. Laragh, J. H., and W. C. Kelly. Aldosterone: its biochemistry and physiology in Advances in Metabolic Disorders, R. Levine and R. Luft, Eds. New York, Academic Press, 1964, p. 231.

44. Imrie, M. J., J. N. Mills, and K. S. Williamson. Circadian variations in renal and adrenal function in Hormones and the Kidney. Proceedings of the Society of Endocrinology, 89th Meeting, Cambridge, Mass., 1962, P. C. Williamson, Ed. New York, Academic Press, 1963, p. 10.

45. Pitts, R. Physiology of the Kidney and Body Fluids. Chicago, Yearbook, 1963, p. 194.

46. Slater, J. D. H., P. Mestitz, G. Walker, and J. D. N. Nabarro. The acute effects of infused adrenal steroids on renal function in adrenalectomized dogs. Acta endocr. (Kbh.) 1961, 37, 263.
47. Bartter, F. C., and E. G. Biglieri. Primary aldosteronism: clinical staff conference at the $\mathrm{Na}$ tional Institutes of Health. Ann. intern. Med. 1958, 48, 647.

48. George, J. M., G. Saucier, and F. C. Bartter. Is there a potent, naturally occurring sodium-losing steroid hormone? J. clin. Endocr. 1965, 25, 621.

49. Daughaday, W. H., and C. M. MacBryde. Studies of the urinary steroid excretion during $\mathrm{Na}^{+}$deprivation and administration of DCA and ACTH in Proceedings of the First Clinical ACTH Conference, J. R. Mote, Ed. Philadelphia, Blakiston, 1950 , p. 152 . (See comments by Thorn, Bartter, Tyler, and Soffer).

50. McIntosh, H. W., H. T. McAlpine, B. Singer, and M. M. Hoffman. Administration of ACTH to normals and patients with intra and extra sellar pituitary tumors in Proceedings of the First Clinical ACTH Conference, J. R. Mote, Ed. Philadelphia, Blakiston, 1950, p. 14.

51. Helper, H. N., R. Lubschez, K. Hain, and M. G. Wilson. Effect of ACTH in children in Proceedings of the First Clinical ACTH Conference, J. R. Mote, Ed. Philadelphia, Blakiston, 1950, p. 419.

52. Tait, J. F., and S. A. S. Tait. Assay of aldosterone and metabolism in Methods in Hormone Research, R. I. Dorfman, Ed. New York, Academic Press, 1962, vol. 1, p. 270.

53. Bayliss, R. I. S. Role of adrenocortical and pituitary hormones in water and electrolyte control in Modern Trends in Endocrinology, H. G. Hill, Ed. New York, Paul Hoeber, 1958, p. 123.

54. Coppage, W. S., Jr., and G. W. Liddle. Metabolic studies with a steroid isolated from the urine of patients with "salt-losing" congenital adrenal hyperplasia. J. clin. Endocr. 1960, 20, 729. 